\title{
Postprandial oxidative losses of dietary leucine depend on the time interval between consecutive meals: a model study with rats
}

\author{
J. Myszkowska-Ryciak ${ }^{1,2,3}$, J.S. Keller', J. Bujko', J. Stankiewicz-Ciupa', R.E. Koopmanschap² \\ and V.V.A.M. Schreurs ${ }^{2}$ \\ ${ }^{1}$ Warsaw University of Life Sciences - SGGW, Department of Dietetics \\ Nowoursynowska 159C, 02-776 Warsaw, Poland \\ ${ }^{2}$ Wageningen University, Wageningen Institute of Animal Sciences (WIAS), Human and Animal Physiology Group \\ Haarweg 10, NL-6709 PJ, Wageningen, the Netherlands
}

KEY WORDS: consecutive meals, time intervals, breath test, $\left[1-{ }^{13} \mathrm{C}\right]$ - leucine oxidation, rat

Received: 7 January 2014

Revised: 15 January 2015

Accepted: 16 March 2015

\footnotetext{
${ }^{3}$ Corresponding author:

email: joanna_myszkowska_ryciak@sggw.pl
}

\begin{abstract}
Postprandial oxidative losses of egg white-bound $\left[1-{ }^{13} \mathrm{C}\right]$-leucine were studied as ${ }^{13} \mathrm{C}$ recovery in the breath of rats in relation to different time intervals between two meals. Male Wistar rats $(n=48 ; 68.3 \pm 5.9 \mathrm{~g})$ divided into 4 groups ( $n=12)$ were fed two meals a day ( $9: 00$ and 16:30; interval $7 h$ ) of a $13.2 \%$ egg white-based diet for 30 min. After 14 days, 3 out of the 4 groups received the $2^{\text {nd }}$ meal at shorter time intervals of 3,1 , and $0 \mathrm{~h}$. Two $\left[{ }^{13} \mathrm{CO}_{2}\right]$ breath tests (BT) were performed on days 19 and 40. The breath samples were analyzed for ${ }^{13} \mathrm{C}$ Atom \% (At \%) enrichment by IRMS, and the results were expressed as the rate of ${ }^{13} \mathrm{C}$ At $\%$ excess and cumulative recovery (\% of dose). The $7 \mathrm{~h}$ interval group showed higher ${ }^{13} \mathrm{C}$ cumulative recovery after the $2^{\text {nd }}$ meal during both the BT and after the $1^{\text {st }}$ meal on the day 40 BT compared with the 3,1 , and $0 \mathrm{~h}$ intervals. In groups with the 3,1 , and $0 \mathrm{~h}$ intervals, the cumulative recovery of ${ }^{13} \mathrm{C}$ after the $2^{\text {nd }}$ meal was lower compared with the $1^{\text {st }}$ meal due to interaction between meals, which probably caused dilution of the tracer in the larger volume of feed in the rat's stomach. On day 40 , all cumulative recovery values were higher than on day 19. An important finding of this study is that despite the differences in postprandial Leu oxidation among interval groups, the weight gain of all rats was similar.
\end{abstract}

\section{Introduction}

Periodic eaters consume their total daily amount of feed in a restricted number of meals. This eating pattern should allow for storing nutrients during the postprandial phase (PP) to meet requirements between meals during the postabsorptive phase (PA) (Schreurs et al., 1997). The processes of protein loss during fasting and protein gain after feeding are called 'diurnal protein cycling' (Millward, 1995). After digestion and absorption, amino acids (AAs) from dietary proteins enter the free amino acids pool of the body and mix with endogenous amino acids. The metabolic utilization of dietary AAs may range from incorporation into body proteins to excretion as metabolic end products as $\mathrm{CO}_{2}, \mathrm{H}_{2} \mathrm{O}$, urea (mammals) or uric acid (birds), and these processes might occur independently and concomitantly in 
the body. The body pool of free AAs is kept small and constant relative to the amounts absorbed from dietary protein intake and the amount involved in body protein turnover. Absorbed dietary AAs, not used for protein synthesis, are channeled into energy metabolism (Schreurs et al., 1997). Postprandial storage of dietary amino acids can be impaired when postprandial oxidation of dietary amino acids is favored by, e.g., an excessively high appearance rate in the blood (Bos et al., 2003). Net protein synthesis can be influenced by endogenous factors (e.g., age, physiological condition, gender) as well as by exogenous ones (e.g., protein and energy intake, protein quality, protein bound vs free amino acids; Metges et al., 2000; D’Mello, 2003; Nolles et al., 2009).

An optimal nutritional strategy should channel dietary AAs into protein synthesis to minimize their PP oxidative losses. Feeding frequency and meal size are important nutritional factors that can influence the protein metabolism of the body. Studies on AA utilization in rats and fish suggest that the same marginal daily amount of food served as small and more frequent meals might improve protein utilization compared with less frequent larger meals (Schiffelers et al., 1996; Bujko et al, 1997, 2004; Borne et al., 2006; Ganzon-Naret, 2013). In the case of lower postprandial oxidation, more AAs remain available in the body until the PA phase to support growth, maintenance processes, or other functions, e.g., immune response (Bujko et al., 2004). On the other hand, increasing the number of meals from 2 to 4 and maintaining a constant feed dose (protein) for 25 days in growing rat females did not result in any significant impact on dietary protein utilization as measured by excretion of nitrogen and body weight gain (Myszkowska-Ryciak et al., 2006). In humans El-Khoury et al. (1995) reported even better 24-h leucine balance with three discrete meals compared with multiple small repeated meals. Similarly, Ohkawara et al. (2013) observed that increasing meal frequency from three to six meals per day has no significant effect on 24-h fat oxidation, but may increase hunger and the desire to eat.

It is hypothesized that the oxidative loss of dietary AAs during the PP phase of consecutive meals is modulated by the time interval between them. Due to metabolic adaptation, the interactions between consecutive meals might be changed after a period of conditioning on the experimental feeding schedule.

The aim of this study was to investigate the influence of different time intervals between two consecutive equal meals on PP oxidative losses of label from egg white-bound $\left[1-{ }^{13} \mathrm{C}\right]$-leucine present in the experimental meal by use of a $\left[{ }^{13} \mathrm{CO}_{2}\right]$ breath test technique. $\mathrm{A}\left[{ }^{13} \mathrm{CO}_{2}\right]$ breath test is a simple and non-invasive method widely used in diagnostic applications as well as in studies on metabolic utilization of amino acids during the PP and/or PA phase of a meal (Raguso et al., 1999; Klein, 2001; Bujko et al., 2007). Body weight gain of the animals was monitored to reflect long-term protein utilization. Breath test (BT) results $\left({ }^{13} \mathrm{C}\right.$ At $\%$ excess in expired $\mathrm{CO}_{2}$ and total cumulative recovery of ${ }^{13} \mathrm{C}(\%$ of dose $/ 5 \mathrm{~h}$ ) were compared at days 19 and 40 to study possible metabolic adaptation to the experimental feeding strategy. The protocol of the experiment was approved by the Ethics Committee of Wageningen University, Wageningen (the Netherlands).

\section{Material and methods}

\section{Animals}

Male WU-Wistar rats ( $\mathrm{n}=48,3-4$ weeks; Center for Small Laboratory Animals, Wageningen University, Wageningen, the Netherlands) were randomly divided into 4 experimental groups $(n=12)$ and caged individually at $22^{\circ} \mathrm{C}$ and $70 \%$ humidity with $16 \mathrm{~h}$ of artificial light and $8 \mathrm{~h}$ of red light (9:00-17:00). Drinking water was available ad libitum during the whole experiment.

\section{Body weight gain}

Body weight of individual animals was determined daily between 8:30 and 9:00 in the morning prior to feeding.

\section{Feeding strategy}

All animals were fed two equal meals a day for 30 min at 9:00 and 16:30 with a time interval of $7 \mathrm{~h}$ for 14 days. Total feed intake was monitored daily; the amount of feed for all rats for the next day was adjusted to the least eating rat. As a consequence all rats were served the same amount of feed every day.

After 2 weeks (on day 15) the time interval between meals was decreased for 3 groups to 3,1 , or $0 \mathrm{~h}$, and for one group the interval remained at $7 \mathrm{~h}$. The $7 \mathrm{~h}$ interval group was considered to follow the natural eating pattern of rats, whereas the $0 \mathrm{~h}$ interval group mimicked the consumption of one large meal daily. The two other time intervals were chosen to examine the utilization of AAs when the meal pattern entailed frequent or somewhat less frequent meals. Starting from day 18, the amount of feed was established at $11 \mathrm{~g}$ per day (according to the least eating rat) and maintained up to day 40 . The meals during breath test (BT) measurements were reduced by $10 \%$ to the amount of $5 \mathrm{~g}$ each to eliminate possible refusals and to make the results comparable. 
Table 1. Composition of experimental diets

\begin{tabular}{|c|c|}
\hline Item & Diet, $\mathrm{g} \cdot 1000 \mathrm{~g}^{-1}$ \\
\hline \multicolumn{2}{|l|}{ Feed ingredients } \\
\hline dextrose & 194.5 \\
\hline wheat starch & 475.0 \\
\hline egg white powder & 132.0 \\
\hline soya oil & 50.0 \\
\hline cellulose & 75.0 \\
\hline vitamin premix & 10.0 \\
\hline mineral premix & 12.0 \\
\hline $\mathrm{CaCO}_{3}$ & 19.0 \\
\hline $\mathrm{NaH}_{2} \mathrm{PO}_{4} \cdot 2 \mathrm{H}_{2} \mathrm{O}$ & 6.5 \\
\hline $\mathrm{KHCO}_{3}$ & 10 \\
\hline $\mathrm{KH}_{2} \mathrm{PO}_{4}$ & 14 \\
\hline $\mathrm{MgO}$ & 1.5 \\
\hline $\mathrm{KCl}$ & 0.5 \\
\hline \multicolumn{2}{|l|}{ Analysed values } \\
\hline crude protein & 128.0 \\
\hline crude fat & 50.0 \\
\hline crude fibre & 73.0 \\
\hline alanine & 7.6 \\
\hline arginine & 7.1 \\
\hline asparagine & 14.3 \\
\hline glutamine & 15.9 \\
\hline glycine & 4.2 \\
\hline histidine & 3.6 \\
\hline isoleucine & 7.3 \\
\hline leucine & 10.7 \\
\hline lysine & 7.6 \\
\hline methionine & 4.5 \\
\hline methionine + cysteine & 6.9 \\
\hline phenylalanine + tyrosine & 12.8 \\
\hline proline & 5.2 \\
\hline serine & 9.7 \\
\hline threonine & 6.2 \\
\hline tryptophan & 2.4 \\
\hline valine & 10.2 \\
\hline
\end{tabular}

vitamin mix $10.1 \mathrm{~g} \cdot \mathrm{kg}^{-1} ;$ mineral mix $12.1 \mathrm{~g} \cdot \mathrm{kg}^{-1}$

During both the preliminary and experimental periods, the rats received the feed in pellet form. Four days prior to breath tests and during both BT measurements, the pellets were powdered and mixed with water to mash form.

\section{Diet}

Starting from day 1 all animals received a diet based on egg white protein $\left(13.2 \%\right.$; $\left.15.2 \mathrm{~kJ} \mathrm{ME} \cdot \mathrm{g}^{-1}\right)$ in line with the requirements of rats (NRC, 1995). The diet composition is shown in Table 1. In the breath test meal (BTM), part of the protein was replaced by egg white with bound $\left[1-{ }^{13} \mathrm{C}\right]$-leucine (about 1.48 At $\%$ excess) produced according to the method by Evenepoel et al. (1997). During BTM the rats received $5 \mathrm{~g}$ of feed containing $0.66 \mathrm{~g}$ of protein $(47 \mathrm{mg}$ of non-labelled leucine and $6 \mathrm{mg}$ of $\left[1-{ }^{13} \mathrm{C}\right]$-leucine).

\section{$\left[{ }^{13} \mathrm{CO}_{2}\right]$ breath test}

$\left[{ }^{13} \mathrm{CO}_{2}\right]$ breath tests were performed on days 19 and 40 of the experiment to monitor dietary AA utilization. For BT measurements half of the animals from each experimental group $(\mathrm{n}=6)$ were given the tracer as a part of the $1^{\text {st }}$ meal at 9:00. The other half of the animals received the label as a part of the $2^{\text {nd }}$ meal, served after the appropriate time interval. The same animals were used on days 19 and 40. During the BT measurements the animals were individually kept in air-tight, macrolon cages $(20 \mathrm{~cm} \times 16 \mathrm{~cm} \times 14 \mathrm{~cm})$ bedded with sawdust and with access to water ad libitum. Every $30 \mathrm{~min}$ an air sample from the cage was taken with a $50 \mathrm{ml}$ syringe to analyze the ${ }^{13} \mathrm{C}$ At $\%$ excess content. Air sampling started $30 \mathrm{~min}$ prior to the BTM to get a blank value for the natural ${ }^{13} \mathrm{C}$ enrichment of expired air. After each air sampling the rat was transferred to another cage with fresh air to start the next $30 \mathrm{~min}$. Depending on the feeding schedule, the meals were presented in the cage at the appropriate time. In total, 11 breath samples were collected during $5.5 \mathrm{~h}$ of measurements for each animal.

The collected air samples were analyzed by a isotope ratio mass spectrometer (Finnigan MAT, Delta $\mathrm{C}$, Bremen, Germany) for ${ }^{13} \mathrm{C}$-enrichment at the WIAS IRMS Laboratory with an accuracy of $\pm 0.0005 \%$.

The ${ }^{13} \mathrm{C}$ At $\%$ excess values (formula below) were plotted vs time.

$$
\begin{gathered}
\text { At } \% \text { Excess }{ }^{13} \mathrm{C} \%=\text { At } \%{ }^{13} \mathrm{C} \text { (sample } \mathrm{n} \text { ) - At } \% \\
{ }^{13} \mathrm{C} \text { (sample } 0 \text { ). }
\end{gathered}
$$

The values for total cumulative recovery of label ( $\%$ of dose recovered in $5 \mathrm{~h}$ ) were obtained by summation of the amounts of label recovered in the sampling periods, and account being taken for $\mathrm{CO}_{2}$ production during the sampling periods.

Expiration rate $(\%$ dose $/ \mathrm{h})=\left[\left({ }^{13} \mathrm{C}\right.\right.$ At $\%$ excess $\times \mathrm{C}$ expired $/ \mathrm{min} \times 60 \mathrm{~min}) /$ dose $\left.{ }^{13} \mathrm{C}\right] \times 100 \%$,

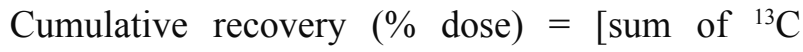
recovery in each sampling period / dose] $\times 100 \%$.

\section{$\mathrm{CO}_{2}$ production}

A value for $\mathrm{CO}_{2}$ production is required to calculate the absolute ${ }^{13} \mathrm{C}$ recovery in expired air. In the present study, $\mathrm{CO}_{2}$ production was measured for 8 rats (4 on day 19 BT, 4 on day 40 BT) from each time interval group by means of indirect calorimetry under conditions identical to the $\left[{ }^{13} \mathrm{CO}_{2}\right]$ breath test. The normal feeding procedure was followed and measurements for 


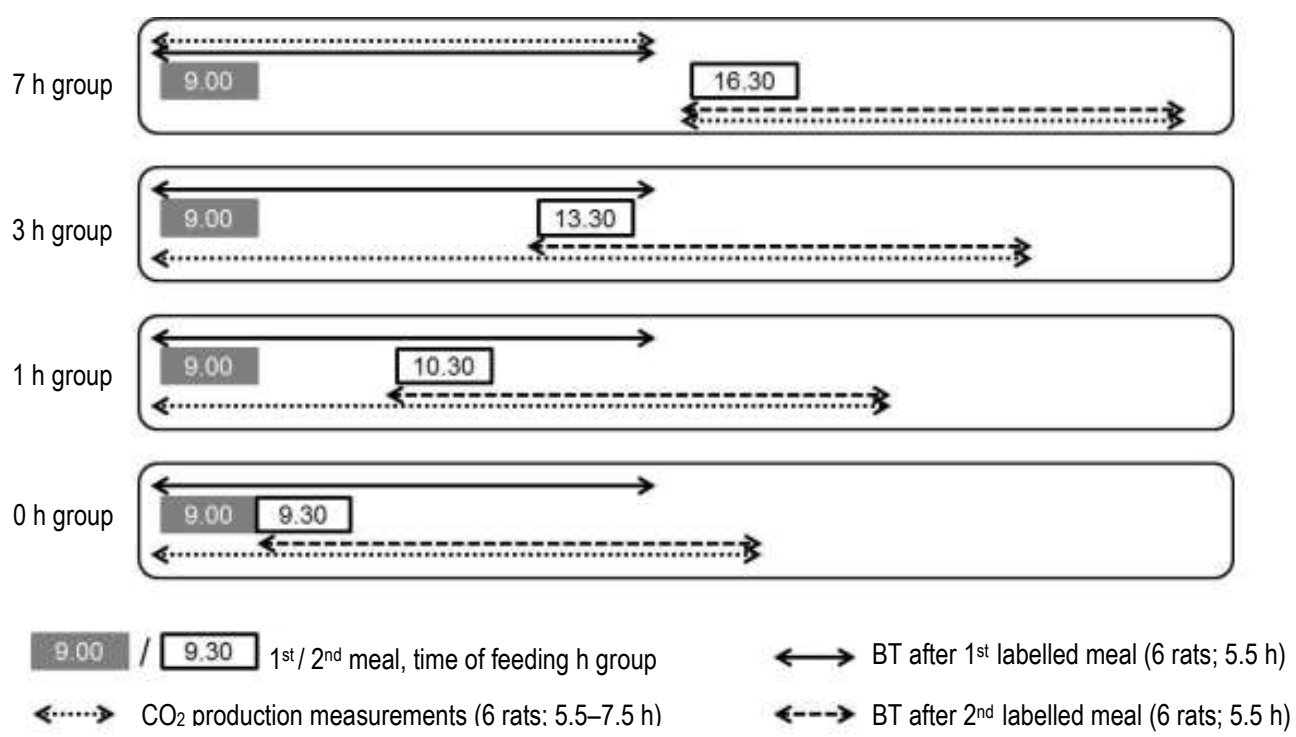

Figure 1. Scheme of the breath test/ $\mathrm{CO}_{2}$ measurements procedure. In each interval group half of rats received $\left[1-^{13} \mathrm{C}\right]$-leucine in $1^{\text {st }}$ meal $\left(2^{\text {nd }}\right.$ meal not labelled $)$ and the other half in $2^{\text {nd }}$ meal $\left(1^{\text {st }}\right.$ meal not labelled $)$

individual rats lasted for at least $5 \mathrm{~h}$ after the breath test meal. The cages were continuously ventilated with fresh air (about $0.51 \cdot \mathrm{min}^{-1}$ ). The outgoing air was dried over $\mathrm{CaCl}_{2}$ and the $\mathrm{CO}_{2}$ content of the air flow was measured using a continuous flow $\mathrm{CO}_{2}$ analyzer (Uras-3G, Hartmann \& Braun AG, Germany). $\mathrm{CO}_{2}$ production was calculated as the average value for $30 \mathrm{~min}$ for individual rats. The values for $\mathrm{CO}_{2}$ production $\left(\mathrm{ml} \cdot \mathrm{min}^{-1}\right)$ were corrected for standard conditions $\left(0^{\circ} \mathrm{C}, 760 \mathrm{~mm} \mathrm{Hg}\right.$, dry air).

The scheme of experimental procedure: labelled meals, breath tests, and $\mathrm{CO}_{2}$ measurements is presented in Figure 1.

\section{Statistical analysis}

ANOVA/MANOVA variance analysis and the post-hoc LSD test (Statistica 10.0 StatSoft, USA for Windows) were used to determine differences, which were considered statistically significant at $P<0.05$. Separate models were used to test: 1 . the effect of different time interval on leucine utilization, 2. the effect of adaptation on leucine utilization, 3. the effects of interval and adaptation on leucine utilization.

\section{Results}

\section{Body weight growth rate}

Table 2 presents the rats' average weight at the beginning of the experiment and on day 19 and 40 . There were no significant differences in initial body weight or in weight gain during the experimental period among the different interval groups.
Table 2. Average weight ( $g$, mean $\pm S D$ ) of rats at the beginning of experiment and during breath test measurements

\begin{tabular}{llll}
\hline $\begin{array}{l}\text { Time interval } \\
\text { groups, } \mathrm{h}\end{array}$ & Day 1 & Day 19 BT & Day 40 BT \\
\hline 7 & $67.0 \pm 3.9$ & $133.4 \pm 4.2$ & $180.8 \pm 2.4$ \\
3 & $69.0 \pm 8.3$ & $134.3 \pm 5.7$ & $175.3 \pm 6.3$ \\
1 & $69.0 \pm 5.6$ & $136.5 \pm 8.2$ & $180.1 \pm 8.2$ \\
0 & $68.0 \pm 6.0$ & $129.2 \pm 10.1$ & $177.8 \pm 6.6$ \\
average & $68.3 \pm 5.9$ & $133.4 \pm 7.9$ & $178.5 \pm 6.6$ \\
\hline
\end{tabular}

BT - breath test

\section{$\mathrm{CO}_{2}$ production}

$\mathrm{CO}_{2}$ production under the conditions of day 19 BT and day 40 BT (Figure 2) is presented as an average value measured in 16 animals. Carbon dioxide production decreased slightly after 17:00 in the group with the $7 \mathrm{~h}$ interval after the $2^{\text {nd }} \mathrm{BTM}$ due to the change in the light period (less active). The $\mathrm{CO}_{2}$ production measured on day 40, on larger animals $(+33 \%)$, was higher compared with day 19. However, the results showed no significant differences in either time or among different time-interval groups. Therefore, the mean values of $\mathrm{CO}_{2}$ production for all animals $\left(0.151 \mathrm{CO}_{2} / 30 \mathrm{~min}\right.$ for day $19 \mathrm{BT}$ and $0.191 \mathrm{CO}_{2} / 30 \mathrm{~min}$ for day $40 \mathrm{BT}$ ) were used for BT calculation.

\section{$\left[{ }^{13} \mathrm{CO}_{2}\right]$ breath test}

The ${ }^{13} \mathrm{C}$ recovery of orally ingested egg whitebound $\left[1-{ }^{13} \mathrm{C}\right]$-leucine as part of the BTM was monitored for $5 \mathrm{~h}$ after the meal as $\left[{ }^{13} \mathrm{CO}_{2}\right]$ in the breath. The pattern of ${ }^{13} \mathrm{C}$ recovery during the $\mathrm{BT}$ is presented as ${ }^{13} \mathrm{C}$ At $\%$ excess plotted against time. 


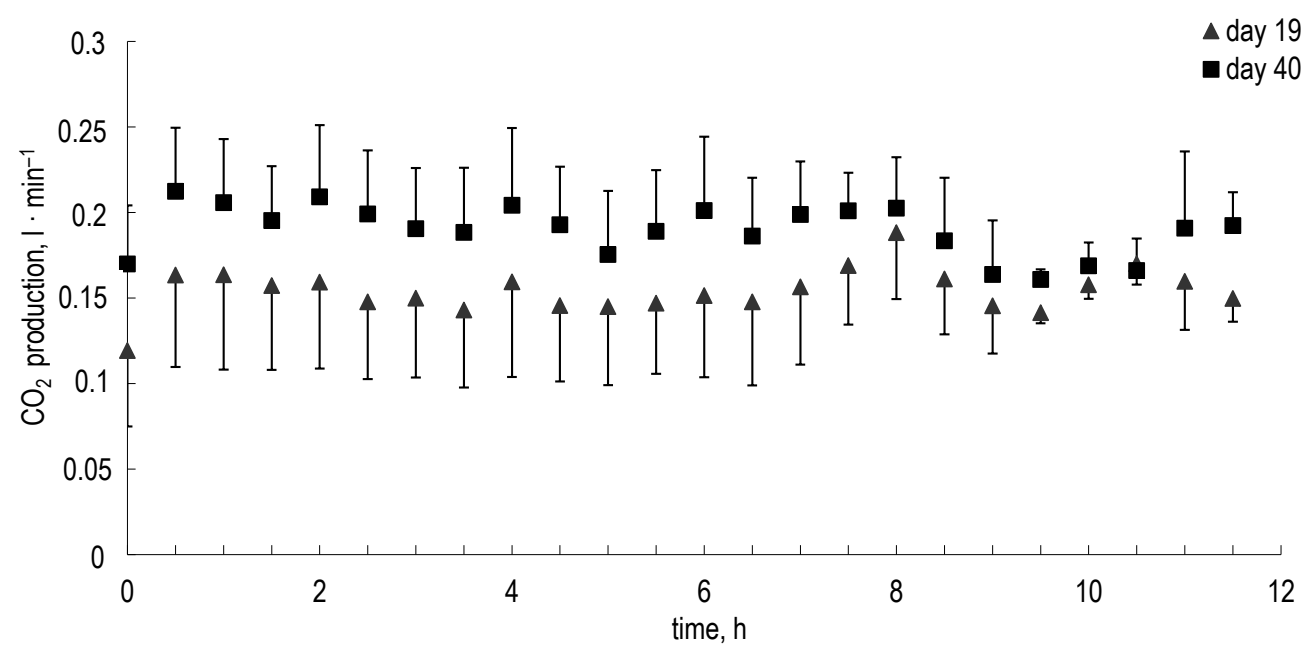

Figure 2. Average $\mathrm{CO}_{2}$ production (mean $\pm \mathrm{SD}$ ) measured during day 19 and day 40 under breath test condition

The $1^{\text {st }}$ BT was performed on day 19 of the experiment, 4 days after introducing the experimental time intervals between meals. The results (Figure 3) showed that in all cases, ${ }^{13} \mathrm{C}$ enrichment increased above the background level within $30 \mathrm{~min}$. In no case did the value of ${ }^{13} \mathrm{C}$ enrichment return to the background level after $5 \mathrm{~h}$ of measurements, and it usually remained between $0.004 \%(0,1 \mathrm{~h}$ intervals $)$ and $0.009 \%$ ( $7 \mathrm{~h}$ interval). In the group with the $7 \mathrm{~h}$ interval, a similar pattern of ${ }^{13} \mathrm{C}$ At $\%$ excess was observed for the $1^{\text {st }}$ and $2^{\text {nd }}$ BTM. When the interval between meals was reduced $(3,1$, and $0 \mathrm{~h}$ ), the pattern of ${ }^{13} \mathrm{C}$ enrichment from the $1^{\text {st }}$ and $2^{\text {nd }} \mathrm{BTM}$ changed reflecting the interactions between consecutive meals on PP leucine utilization.
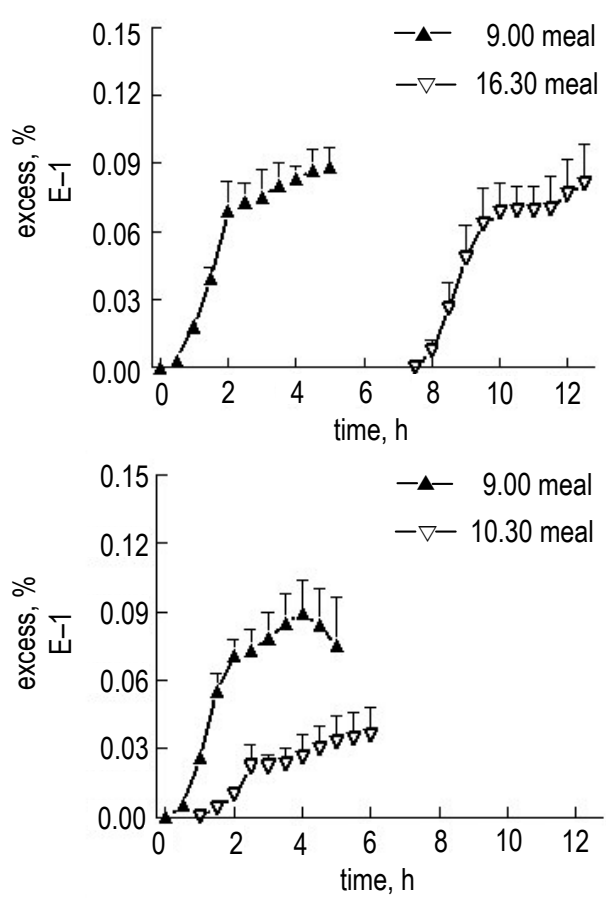

The ${ }^{13} \mathrm{C}$ At $\%$ excess after the $1{ }^{\text {st }} \mathrm{BTM}$ in the group with the $7 \mathrm{~h}$ interval increased rapidly to a value of $0.007 \%$ after $2 \mathrm{~h}$. Thereafter the rate of increase slowed, and after $5 \mathrm{~h}$ a value of $0.009 \%$ was reached. The curve from the $2^{\text {nd }}$ BTM was similar and reached a maximal value of $0.008 \%$ after $5 \mathrm{~h}$. When the $2^{\text {nd }}$ meal was given after a shorter time interval, the ${ }^{13} \mathrm{C}$ excess of both meals was affected. With an interval of $3 \mathrm{~h}$, the response to the $1^{\text {st }} \mathrm{BTM}$ reached a level of $0.009 \%$ within $2 \mathrm{~h}$ and remained practically constant thereafter. The ${ }^{13} \mathrm{C}$ enrichment curve for the $2^{\text {nd }}$ BTM reached a plateau of ca $0.005 \%$ after $3.5 \mathrm{~h}$. When the interval was reduced to $1 \mathrm{~h}$, the label recovery from the $1^{\text {st }}$ BTM increased in the first $4 \mathrm{~h}$ to $0.009 \%$ and then started to decline.
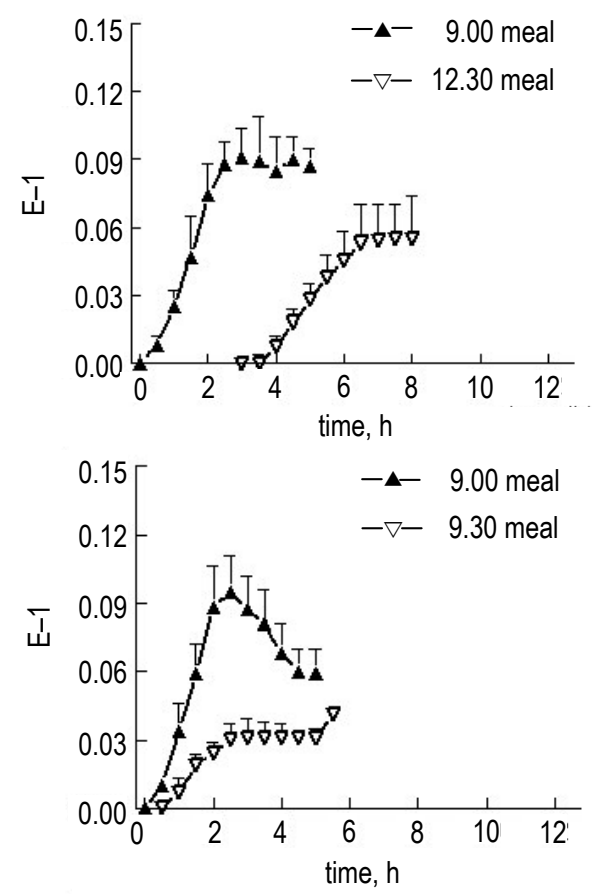

Figure 3. Rate of ${ }^{13} \mathrm{C}$ enrichment in breath (At \% excess $\pm \mathrm{SD}$ ) derived from egg white bound $\left[1-{ }^{13} \mathrm{C}\right]$-leucine present in $1{ }^{\text {st }}$ or $2^{\text {nd }}$ meal in groups fed with time intervals of 7, 3, 1 and $0 \mathrm{~h}$ during day 19 breath test 
The curve of the ${ }^{13} \mathrm{C}$ excess from the $2^{\text {nd }} \mathrm{BTM}$ showed a biphasic increase to a value of $0.004 \%$ after $5 \mathrm{~h}$. The curve of ${ }^{13} \mathrm{C}$ enrichment from the $1{ }^{\text {st }}$ BTM in the group with $0 \mathrm{~h}$ interval dramatically increased to a peak value of $0.01 \%$ within $2.5 \mathrm{~h}$ and then started to decline reaching $0.006 \%$ after $5 \mathrm{~h}$. When the label was introduced in the $2^{\text {nd }}$ meal, the curve of ${ }^{13} \mathrm{C}$ excess reached a plateau of about $0.003 \%$ after $2 \mathrm{~h}$.

Results of the day $40 \mathrm{BT}$ are presented in Figure 4. In general, the patterns of the curves of
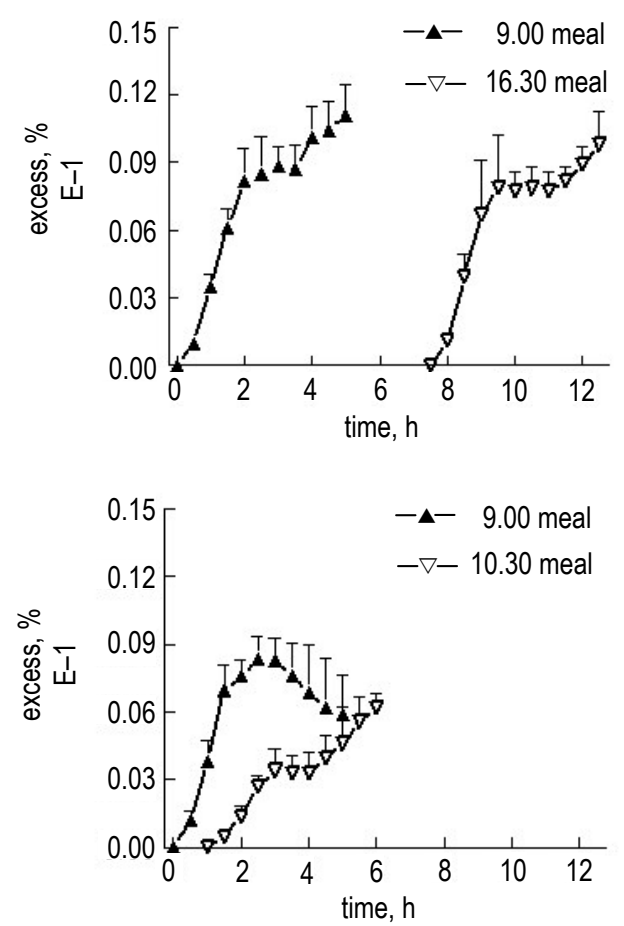

${ }^{13} \mathrm{C}$ excess were similar to those observed on day 19 , especially during the first $3 \mathrm{~h}$ of measurements. However, all values were slightly higher compared with the day 19 BT. During the last $2 \mathrm{~h}$ of BT measurements, all values of ${ }^{13} \mathrm{C}$ enrichment tended to increase compared with day $19 \mathrm{BT}$.

The results of the total cumulative recovery of ${ }^{13} \mathrm{C}$ from labelled leucine are presented in Figure 5.

Application of the label into the $1^{\text {st }} \mathrm{vs} 2^{\text {nd }}$ meal significantly influenced the cumulative recovery
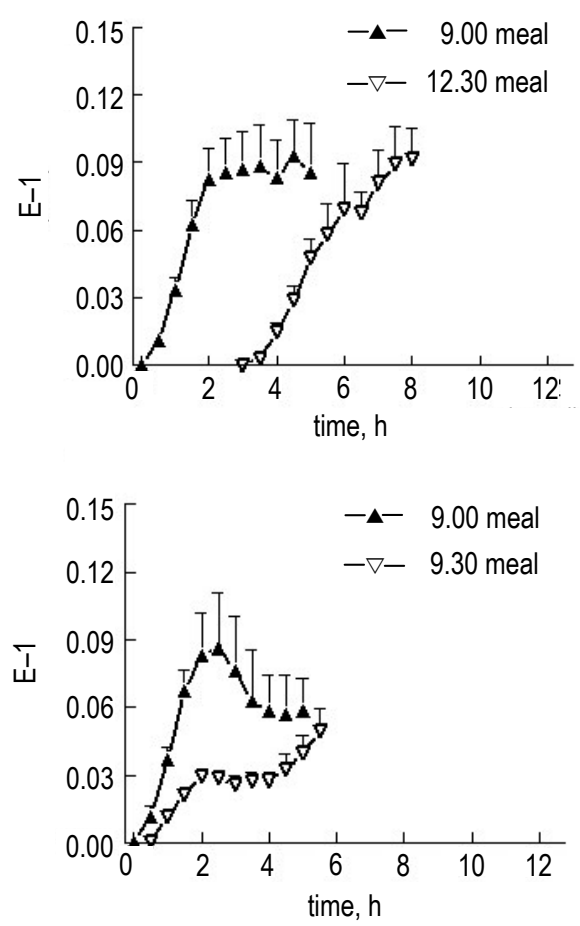

Figure 4. Rate of ${ }^{13} \mathrm{C}$ enrichment in breath (At \% excess $\pm \mathrm{SD}$ ) derived from egg white bound $\left[1-{ }^{13} \mathrm{C}\right]-$ leucine present in $1{ }^{\text {st }}$ or $2^{\text {nd }}$ meal in groups fed with time intervals of $7,3,1$ and $0 \mathrm{~h}$ during day 40 breath test
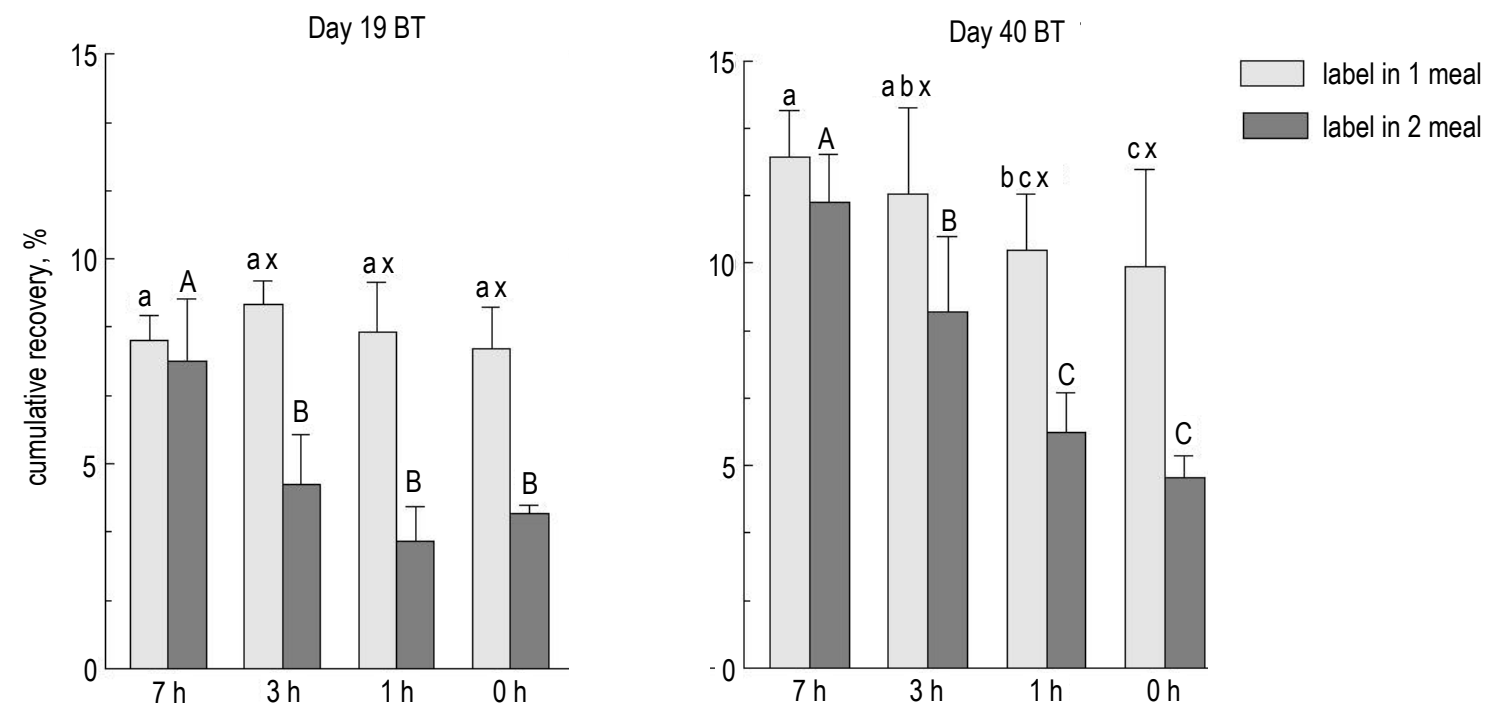

Figure 5 . The total ${ }^{13} \mathrm{C}$ cumulative recovery of label introduced in $1^{\text {st }}$ or $2^{\text {nd }}$ meal after $5 \mathrm{~h}$ of breath test measurements (BT) in groups fed with different time interval $\left(7,3,1\right.$ and $0 \mathrm{~h}$ ) between meals (means $\pm \mathrm{SD}$ ). $\mathrm{x}$ - statistically significant difference between $1^{\text {st }}$ breath test meal (BTM) and $2^{\text {nd }}$ BTM within groups; $a, b, c$ - statistically significant differences between $1^{\text {st }}$ BTM in all intervals groups; A, B, C - statistically significant differences between $2^{\text {nd }}$ BTM in all intervals groups 
of ${ }^{13} \mathrm{C}$, which was significantly higher for the $1^{\text {st }}$ labelled meal in all groups on both breath tests except for the $7 \mathrm{~h}$ interval group. On day 19 there were no differences between the total ${ }^{13} \mathrm{C}$ recovery after the $1^{\text {st }} \mathrm{BTM}$ for all interval groups, whereas on day 40 differences were found. A significantly lower ${ }^{13} \mathrm{C}$ cumulative recovery was observed in groups with $0 \mathrm{~h}$ and $1 \mathrm{~h}$ intervals compared with the $7 \mathrm{~h}$ interval, but there was no difference between the $3 \mathrm{~h}$ and $7 \mathrm{~h}$ interval groups. In case of the $2^{\text {nd }} \mathrm{BTM}$, the total cumulative recovery of ${ }^{13} \mathrm{C}$ was significantly highest in the $7 \mathrm{~h}$ interval group in both BTs and, additionally, on day 40 the $3 \mathrm{~h}$ interval group differed from the others.

\section{Discussion}

The aim of the present study was to test the hypothesis that oxidative losses of dietary $\left[1-{ }^{13} \mathrm{C}\right]-$ leucine during the postprandial phase are modulated by the time interval between meals. In addition we examined if interactions between consecutive meals changed after 3 weeks of conditioning on a specific feeding strategy.

Since the first step of leucine catabolism is irreversible decarboxylation (Newby and Price, 1998), the amount of ${ }^{13} \mathrm{C}$ in the breath, measured after a $\left[1-{ }^{13} \mathrm{C}\right]$-leucine containing meal, reflects irreversible loss of dietary leucine. In other words only nonoxidized leucine remains available for metabolic processes of the body throughout the PA phase. As a consequence, lower total cumulative recovery of label during the PP phase is supposed to reflect a better nutritional situation with respect to utilization of dietary AAs. In humans a rapid, transient response of $\left[{ }^{13} \mathrm{CO}_{2}\right]$ in the breath is observed after ingestion of $\left[{ }^{13} \mathrm{C}\right]$-labelled egg white. The maximal $\left[{ }^{13} \mathrm{C}\right]$ enrichment is reached after about 120-145 $\mathrm{min}$ and then decreases nearly to the background level within 300 min (Ghoos et al., 1998; Geboes et al., 2004). The curve is characterized by an ascending part (charging of the metabolic pool) leading to a peak value for maximal excretion of label and a descending part (clearance of metabolic pool; Schreurs and Krawielitzki, 2003). A $\left[{ }^{13} \mathrm{CO}_{2}\right]$ expiration curve represents the overall result of the flow of orally ingested label through all physiological and metabolic processes (gastric emptying, digestion, absorption, and metabolism). Results of human breath test lead to the conclusion that proteins ingested with a meal are almost immediately released by the stomach to the intestine for digestion and absorption. Therefore, bigger meals are expected to cause a higher appearance rate of amino acids in the blood within a short time (bolus application). As a consequence, higher oxidative losses of dietary AAs could be expected in the PP phase. In such a case the benefit of more frequent smaller meals compared with bigger meals consumed less often is possible and reported in many studies. In animals fed marginal amounts of protein more frequently, an improvement of dietary protein utilization was reflected in better weight gain (Schiffelers et al., 1996), better protein status reflected by AA oxidation, and even better immune response (Heatley, 1995; Bujko et al., 2004; Myszkowska-Ryciak et al., 2006).

As far as the ${ }^{13} \mathrm{C}$ appearance rate in the breath is proportional to meal size without restriction by gastric emptying, small meals consumed with too short time intervals might cause the same or even more negative effects on protein utilization. If a consecutive meal is eaten too early, when oxidation of dietary AAs from the first meal is maximal or on a relatively high level, then the overall oxidative loss is supposed to be higher. Thus, in our model study on rats we expected that with the shorter interval between equal consecutive meals, the cumulative recovery of label would be higher compared with the situation when two meals were more independent.

Our results show that despite meal ingestion taking a maximum of $30 \mathrm{~min}$, the metabolic response, monitored by expiration rate of $\left[{ }^{13} \mathrm{CO}_{2}\right]$ derived from egg white-bound $\left[1-{ }^{13} \mathrm{C}\right]$-leucine present in the meal, was not accomplished within $5 \mathrm{~h}$ as in humans. This suggests that the experimental meal cannot be handled as a 'single' meal (bolus) in rats due to prolonged amino acids oxidation. This might be explained in two ways. First, the handling of dietary amino acids on the metabolic level is not boluslike because of a slow rate of gastric empting and/or digestion and absorption. Alternatively, rapid metabolic availability of amino acids is not followed by rapid and complete metabolic handling because of restricted metabolic capacity. It is remarkable that in our study in rats, one bolus-like meal created a $\left[{ }^{13} \mathrm{CO}_{2}\right]$ response similar to the human response to repeated small boluses (nibbling) or slow protein feeding mimicking a constant feeding pattern (Boirie et al., 1997; Dangin et al., 2001).

It was also observed that responses to meals were independent with a $7 \mathrm{~h}$ interval, as the cumulative values as well as ${ }^{13} \mathrm{C}$ enrichment curves of both BTMs did not differ. A shorter time interval (3, 1, $0 \mathrm{~h}$ ) between the meals influenced the ${ }^{13} \mathrm{C}$ enrichment of expired $\mathrm{CO}_{2}$ after the $1^{\text {st }}$ meal. The changes occurred during the last $3 \mathrm{~h}$ of BT measurements, whereas the patterns of ${ }^{13} \mathrm{C}$ At $\%$ excess during first 
$120 \mathrm{~min}$ were similar for all interval groups. This suggests that a substantial part of the ingested meal is directly transferred to the intestine for digestion and absorption. The rest of the meal remains in the stomach and can be mixed with a consecutive meal depending on the time interval. As a consequence, only part of the first meal is mixed with the $2^{\text {nd }}$ meal in the stomach. Thus, the decrease in label recovery might be explained by dilution of tracer from the $1^{\text {st }}$ meal by the non-labelled leucine in the $2^{\text {nd }}$ meal. This effect is greater with a shorter interval between meals.

The low postprandial ${ }^{13} \mathrm{C}$ cumulative recovery after the $2^{\text {nd }}$ meal (interval 3,1 and $0 \mathrm{~h}$ ) might be explained in a similar way by a 'queue' effect in the stomach. The $2^{\text {nd }}$ meal with $\left[1-{ }^{13} \mathrm{C}\right]-$ leucine was ingested while part of the protein from the $1^{\text {st }}$ meal was still present in the stomach. These effects are also more pronounced with shorter time intervals between consecutive meals.

All values of ${ }^{13} \mathrm{C}$ cumulative recovery from labelled leucine were significantly higher (except the $2^{\text {nd }}$ meal in $0 \mathrm{~h}$ interval) on day 40 than on day 19 of the experiment. The day 40 breath test measurements were performed on bigger animals (about $+33 \%$ ) than on day 19. Thus, the same amount of feed as on day 19 was ingested to an increased stomach storage capacity, where mixing of consecutive meals was improved. Also the gastric empting rate may have been increased as well as intestine capacity might have been improved. As a consequence, a greater amount of tracer was available for metabolism in a shorter time. Furthermore, larger animals with a greater protein mass and lower growth rate have higher unavoidable oxidative maintenance losses of amino acids compared with smaller animals with higher growth rates.

ANOVA results showed an effect of adaptation in different interval groups on day 40 . The feeding conditions (amount of feed and label) were exactly the same during both BT measurements and the rate of growth did not differ among interval groups. Therefore, the lower cumulative recovery of ${ }^{13} \mathrm{C}$ in the 0 and $1 \mathrm{~h}$ interval groups reflected an improvement in utilization of dietary leucine compared with the $7 \mathrm{~h}$ interval. In this case, some gastrointestinal functions could have adapted to a larger amount of protein being ingested in a short time $(0,1 \mathrm{~h}$ intervals) by decreasing the inflow of amino acids to the metabolic pool. Shi et al. (1997) reported that gastric emptying of a protein meal can be modified by previous dietary protein intake during at least 14 days. On the other hand, adaptation to altered feeding by decreasing the oxidation rate through the physiological mechanism of diurnal protein cycling might have occurred. This mechanism may adjust the rate of amino acid utilization after a meal to the composition and amount of diet (Millward, 1995).

Our results show that time intervals between meals modulate oxidative loss of dietary leucine. Because a single meal in rats is not treated like a bolus in the metabolism and because the response is not accomplished within $5 \mathrm{~h}$, the present model study cannot provide a clear conclusion about the overall leucine utilization. However, it can at least be assumed that different time intervals between consecutive meals did not influence long-term protein utilization as measured by growth of the animals. Our observations support the idea of the important role of gastric empting rate on the regulation of amino acid utilization in the rat. The deceleration of gastric empting in response to the saturation of catabolic capacities by a meal high in protein was previously reported by Morens et al. (2000). Türker and Yildirim (2011) showed that because of slower digestion, a six-meal feeding strategy was more efficient in terms of weight gain compared with 2,3 , or 4 meals. The speed of protein digestion and amino acid absorption from the gut also plays an important role for whole-body protein anabolism after a single meal in humans. Boirie et al. (1997) showed that slowly absorbed casein promotes postprandial protein deposition by inhibition of protein breakdown without excessive increase in amino acid concentrations, and on the other hand, a fast dietary protein (whey) stimulates protein synthesis, but also oxidation. It is clear that humans and rats react differently to meal size. In humans the reaction is more restricted by metabolic capacity, whereas in rats the reaction is more influenced by metabolic availability.

The important result of the study is the fact that regardless of the interval between meals and differences in leucine oxidation, weight gain, reflecting the protein status of the animal was the same.

\section{References}

Boirie Y., Dangin M., Gachon P., Vasson M.P., Maubois J.L., Beuufrere B., 1997. Slow and fast dietary proteins differently modulate postprandial protein accretion. Proc. Natl. Acad. Sci. USA 94, 14930-14935

Borne van den J.J., Verstegen M.W., Alferink S.J., Giebels R.M., Gerrits W.J., 2006. Effects of feeding frequency and feeding level on nutrient utilization in heavy preruminant calves. J. Dairy Sci. 89, 3578-3586

Bos C., Metges C.C., Gaudichon C., Petzke K.J., Pueyo M.E., Morens C., Everwand J., Benamouzig R., Tome D., 2003. Postprandial kinetics of dietary amino acids are the main determinant of their metabolism after soy or milk protein ingestion in humans. J. Nutr. 133, 1308-1315 
Bujko J., Myszkowska-Ryciak J., Karwowska W., Koopmanschap R.E., Kuyf B., Zierikzee A., Schreurs V.V.A.M., 2004. The influence of feeding frequency and protein source on protein status and immune response. Polish J. Food Nutr. Sci. 13/54, 15-18

Bujko J., Schreurs V.V.A.M., Koopmanschap R.E., Furstenberg E., Keller J.S., 1997. Benefit of more but smaller meals at a fixed daily protein intake. Z. Ernährungswiss. 36, 347-349

Bujko J., Schreurs V.V.A.M., Nolles J.A., Verreijen A.M., Koopmanschap R.E., Verstegen M.W., 2007. Application of a $\left[{ }^{13} \mathrm{CO}_{2}\right]$ breath test to study short-term amino acid catabolism during the postprandial phase of a meal. Brit. J. Nutr. 97, 891-897

Dangin M., Boirie Y., Garcia-Rodenas C., Gachon P., Fauquant J., Callier P., Ballèvre O., Beaufrère B., 2001. The digestion rate of protein is an independent regulating factor of postprandial protein retention. Amer. J. Physiol.- Endoc. M. 280, E340-E348

D'Mello J.P.F., 2003. Adverse effects of amino acids. In: J.P.F. D'Mello (Editor). Amino Acids in Animal Nutrition. CAB International. Wallingford, Oxon (UK), pp. 125-142

El-Khoury A.E., Sanchez M., Fukagawa N.K., Gleason R.E., Tsay R.H., Young V.R., 1995. The 24-h kinetics of leucine oxidation in healthy adults receiving a generous leucine intake via three discrete meals. Amer. J. Clin. Nutr. 62, 579-590

Evenepoel P., Hiele M., Luypaerts A., Geypens B., Buyse J., Decuypere E., Rutgeerts P., Ghoos Y., 1997. Production of egg proteins, enriched with L-leucine-13C, for the study of protein assimilation in humans using breath test technique. J. Nutr. 127, 327-331

Ganzon-Naret E.S., 2013. Effects of feeding frequency on growth, survival rate and body composition in sea bass (Lates calcarifer) juveniles fed a commercial diet under laboratory condition. ABAH Bioflux 5 (2), 175-182

Geboes K.P., Bammens B., Luypaerts A., Malheiros R., Buyse J., Evenepoel P., Rutgeerts P., Verbeke K., 2004. Validation of a new test meal for a protein digestion breath test in humans. J. Nutr. $134,806-810$

Ghoos Y., Beaufrere B., Dangin M., Boirie Y., Fauquant J., Evenepoel P., Geypens B., Hiele M., Rutgeerts P., 1998. The production of milk and egg proteins, enriched with stable isotopes, for the in vivo study of protein assimilation and metabolism during feeding: an European collaborative study. Gut 43, Suppl., 23-24

Heatley R.V., 1995. The Immune System and Nutrition Support. In: J. Payne-James, G. Grimble, D. Silk (Editors). Artificial Nutrition Support in Clinical Practice. The Bath Press, Avon pp. $99-113$

Klein P.D., 2001. ${ }^{13} \mathrm{C}$ Breath test: visions and realities. J. Nutr. 131, 1637S-1642S

Metges C.C., El-Khoury A.E., Selvaraj A.B., Tsay R.H., Atkinson A., Regan M.M., Bequette B.J., Young V.R., 2000. Kinetics of $\mathrm{L}-[1-13 \mathrm{C}]$ leucine when ingested with free amino acids, unlabeled or intrinsically labelled casein. Amer. J. Physiol. 287, E1000-E1009
Millward D.J., 1995. A protein-stat mechanism for regulation of growth and maintenance of the lean body mass. Nutr. Res. Rev. 8, 93-120

Morens C., Gaudichon C., Metges C.C., Fromentin G., Baglieri A. Even P.C., Huneau J.F., Tomé D., 2000. A high-protein meal exceeds anabolic and catabolic capacities in rats adapted to a normal protein diet. J. Nutr. 130, 2312-2321

Myszkowska-Ryciak J., Keller J., Bujko J., 2006. The influence of feeding frequency on dietary protein utilization - a model study. New Medicine 2, 43-47

Newby D.F., Price S.R., 1998. Determinants of protein turnover in health and disease. Miner. Electrolyte Metab. 24, 6-12

Nolles J.A., Verreijen A.M., Koopmanschap R.E., Verstegen M.W., Schreurs V.V., 2009. Postprandial oxidative losses of free and protein-bound amino acids in the diet: interactions and adaptation. J. Anim. Physiol. Anim. Nutr. (Berl) 93, 431-438

NRC, 1995. Nutrient Requirements of Laboratory Animals, $4^{\text {th }}$ Revised Edition. The National Academies Press. Washington, DC

Ohkawara K., Cornier M.A., Kohrt W.M., Melanson E.L., 2013. Effects of increased meal frequency on fat oxidation and perceived hunger. Obesity 21(2), 336-343

Raguso C.A., Pereira P., Young V.R., 1999. A tracer investigation of obligatory oxidative amino acid losses in healthy, young adults. Amer. J. Clin. Nutr. 70, 474-483

Schiffelers S.L.H., Schreurs V.V.A.M., Krawielitzki K., Koopmanschap R.E., 1996. Effect of meal size on protein metabolism and utilization of dietary amino acids at a marginal level of protein intake. In: A.F. Nunes, A.V. Portugal, J.P.Costa, J.R. Ribero (Editors). Protein Metabolism and Nutrition. Proceedings of the $7^{\text {th }}$ International Symposium on Protein Metabolism and Nutrition. Vale de Santarém (Portugal). EAAP Publication No. 81, 345-347

Schreurs V.V.A.M., Koopmanschap R.E., Boekholt H.A., 1997. Shortterm dynamics in protein and amino acids metabolism. Z. Ernährungswiss 36, 336-339

Schreurs V.V.A.M., Krawielitzki K., 2003. Mathematical analysis of $\left[{ }^{13} \mathrm{CO}_{2}\right]$ - expiration curves from human breath test using $\left[1-{ }^{13} C\right]-$ amino acids as oral substrate. In: W.B. Souffrant and C.C. Metges (Editors). Progress in Research on Energy and Protein Metabolism. Rostock-Wernemunde (Germany). Wageningen Academic Press Publishers. EAAP Publication No. 109, pp. 239-242,

Shi G., Leray V., Scarpignato C., Bentouimou N., Bruley des Varannes S., Cherbut C., Galmiche J.P., 1997. Specific adaptation of gastric emptying to diets with differing protein content in the rats: is endogenous cholecystokinin implicated? Gut 41 , 612-618

Türker A., Yildirim Ö., 2011. The effect of feeding frequency on growth performance and body composition in juvenile rainbow trout (Oncorhynchus mykiss) reared in cold seawater. Afr. J. Biotechnol. 10, 9479-9484 